Journal of Health Promotion and Behavior (2017), 2(3): 282-290

https://doi.org/10.26911/thejhpb.2017.02.03.08

\title{
Factors Associated with Cadre Activities In Jember, East Java
}

\author{
Dewi Nofa Wahyuni'), Hermanu Joebagyo²), Bhisma Murti1) \\ 1)Master Program in Family Medicine, SebelasMaret University \\ 2)Faculty of Teaching and Educational Sciences,SebelasMaret University
}

\begin{abstract}
Background: Since reformation era in 1998, the activities of the integrated health service post (posyandu) have been declining. In order to revitalize posyandu activities, revitalization strategy was introduced. The purpose of this study was to examine factors associated with posyandu cadre activities in Jember, East Java, including the effectiveness revitalization strategy.

Subjects and Method: This was an analytic a cross-sectional study, conducted in Jember, East Java. A sample of 80 integrated health service post (posyandu) cadres was selected for this study. The dependent variable was cadre activity. The independent variables were age, knowledge, education, employment, duration, training, and revitalization strategy. Questionnaire was used to measure variables. Logistic regression was used to analyze data.

Results: Duration $\geq 10$ years $(\mathrm{OR}=1.53 ; 95 \% \mathrm{CI}=0.42$ to $5.61 ; \mathrm{p}=0.524)$, education $\geq$ high school $(\mathrm{OR}=2.35 ; 95 \% \mathrm{CI}=0.47$ to $11.76 ; \mathrm{p}=0.299)$, housewife $(\mathrm{OR}=9.58 ; 95 \% \mathrm{CI}=1.60$ to $57.21 ; \mathrm{p}=$ o.013), ever had training ( $\mathrm{OR}=4.38 ; 95 \% \mathrm{CI}=1.21$ to $15.77 \mathrm{p}=0.024)$, good revitalization strategy $(\mathrm{OR}=3.71 ; 95 \% \mathrm{CI}=1.03$ to $13.36 ; \mathrm{p}=0.045)$ were associated with increased cadre activity. Age 2645 years old $(\mathrm{OR}=0.35 ; 95 \% \mathrm{CI}=0.01$ to $17.81 \mathrm{p}=0.604)$, age $\geq 46$ years old $(\mathrm{OR}=0.18 ; 95 \% \mathrm{CI}=$ 0.01 to $3.66 ; \mathrm{p}=0.262)$, low knowledge $(\mathrm{OR}=0.80 ; 95 \% \mathrm{CI}=0.16$ to $4.02 ; \mathrm{p}=0.786)$, poor knowledge $(\mathrm{OR}=0.40 ; 95 \% \mathrm{CI}=0.06$ to $2.89 ; \mathrm{p}=0.367)$ were associated with decreased cadre activity.

Conclusion: Housewife, ever had training, and good revitalization strategy are factors that increase cadre activity, and they are statistically significant. Age $26-45$ years old, age $\geq 46$ years old, low knowledge, poor knowledge are associated with decreased cadre activity, but they are not statistically significant.
\end{abstract}

Keywords: cadre activity, cadre characteristic, integrated health service post, revitalization strategy

\section{Correspondence:}

Dewi Nofa Wahyuni. Masters Program in Family Medicine, Sebelas Maret University, Jl. Ir. Sutami 36 A, Surakarta 57126, Central Java. Email: dewi.nofa86@gmail.com. Mobile: 081330772655.

\section{BACKGROUND}

Posyandu is one form of Community Based Health Efforts (UKBM) managed and organized from, by, for, and with the community. Posyandu is needed in the implementation of health development, to empower the community and provide convenience to the public in obtaining basic health services to accelerate the decline in maternal and infant mortality (Health Ministry, 2010). To make this program runs properly,it is necessary role of posyandu cadres in every implementation of its activities. Therefore, the cadres must have a good knowledge about the posyandu implementation starting from the duty before the opening day, the duty on the opening day and the duty after the opening day (Ministry of Home Affairs, MOH, MoNE, BKKBN and Unicef, 2012).

Posyandu is the main point of health and nutrition services for mothers and toddlers. Therefore, to optimize the posyandu function, the government takes a 
policy by revitalizing Posyandu, as an effort to improve the function and performance of Posyandu. Generally, the purposes of the programme implementing Posyandu activities on a regular and continuous basis, achieving empowerment of community leaders and cadres through advocacy, orientation and training as well as achieving institutional consolidation Posyandu (Health Ministry RI, 2006).

Posyandu revitalization does not play a role in the function of medical service or medical fulfillment, but rather emphasize on the approach strategy of Community Health Effort (UKBM) with access to sociocultural capital of society based on the values of traditions "gotong-royong" (mutual cooperation) that have been rooted in the community life towards independence and self-reliance (MOHA, 2001).

The problem that often arises is that the posyandu cadres are more likely asan executor of the activity, not the managers. So in performing the task as a cadre, it is limited to the time of its implementation itself, while at the time of preparation and evaluation, itcannot be implemented maximally (Martika, 2011). Being able to carry out these roles and functions, posyandu cadres must have good knowledge on the implementation of posyandu (Depdagri, 2010).

Proclaimed in 1984, the growth of posyanduhas grown rapidly. Last year, it was detected that a number of posyandu in Indonesia until the end of 2015 were 266,827 posyandu. While in East Java it was 44,355 posyandu (Bankdata $\mathrm{MOH}$, 2015). In Jember, the number of Posyandu was recorded as 1,699 posyandu (Jember District Health Office, 2015).

As an illustration, the number of cadre needs in Jember Kidul Public Health Center is 175 cadres, but having just been fulfilled by 173 cadres (98.67\%). The number of active cadres from 173 cadres was 171 people (98.84\%). While the number of cadres needs in the work area of Puskesmas Arjasa Jember is 165 cadres, but in reality only met 157 cadres (95.15\%). The number of active cadres of 157 cadres was 121 persons (73.33\%), due to inactive cadres causing the duty of cadres to be congruent with this condition encouraging the non-implementation of the role of cadres outside posyandu. It is seen that Puskesmas Arjasa which majority have not reached Posyandu Purnamais still really far from the level of activeness of its cadre compared with Puskesmas Jember Kidul which has reached Posyandu Purnama.

The Efforts to build prosperous families and empowerment of midwives can not be separated. Midwives are at the forefront of building a prosperous family from the point of health and other empowerment. Midwives occupy a strategic position because usually at the village level is a rare professional group. The Indonesian community and family in the village, in an almost unprepared condition, face a very powerful youth explosion. Midwives can take a very important role in helping Indonesian families deliver children and youth to build themselves and their nation (Hayono, 2012).

Midwife strategy in empowering Posyandu among others is by motivating and improving community participation in the implementation of Posyandu, for example providing stimulus in the form of constructive reward for people who are actively involved in the implementation of posyandu (Astuti, 2012).

Posyandu is a place to get basic services, especially in the field of health and family planning managed by the community, the implementation is carried out by cadres who have been trained in the field of health and family planning, whose 
Journal of Health Promotion and Behavior (2017), 2(3): 282-290

https://doi.org/10.26911/thejhpb.2017.02.03.08

members come from PKK, public figures and other community. Posyandu is held for the benefit of the community, therefore the community are expected to actively form, organize and utilize it as well as possible in the form of participation in Posyandu every month that aims to improve the nutritional status of children under five (Kemenkes RI, 2001).

The main staff of posyandu is posyandu cadres, whose quality is very decisive in the effort of improving the quality of implemented services. Thus, the cadre's ability should be developed to their potential maximally, with knowledge and skill adjusted to the tasks posed in managing posyandu, in order to play an active role in improving public health. A posyandu cadre is a person who due to his or her ability to be appointed, is elected and or appointed to lead the development of a posyandu in a place or village (Ministry of Health, 2011).

The cadres have a major role to perform services in posyandu, but cadres also have roles outside the posyandu, such as supporting family planning services, KIA, immunization, nutrition and prevention of diarrhea, inviting mothers to come on the day of posyandu activities and supporting other health efforts. inaccordance with the existing problems (Rachman, 2015).

The motivation of human resources in work is strongly influenced by various things and diverse both among individuals and within individuals themselves at differrent times. Motivation is a willingness to expend high levels of effort to achieve organizational goals, conditioned by the ability to meet an individual's needs (Robbins, 2011).

The cadres activeness is one of the successful indicators of the posyanduservice process so that there is no double function of the cadres, for example in two or more service desks it is only served by one cadre due to many inactive cadres (Himawan, 2012).

The purpose of this study is to analyze the influence of cadre characteristic and revitalization strategy in the activeness in posyandu activity in Jember.

\section{Study design}

This was an observational analytic study with cross sectional design. The study was conducted at Posyandu Jember, Jember. East Java, in April 2017.

\section{Population and sample}

The population in this study was all posyandu cadres in Jember. The sampling technique used quota sampling of 80 cadres.

\section{Study variables}

The dependent variable was cadre activity. The independent variables were age, length of time being cadres, knowledge, education, occupation, training, revitalization strategy.

\section{Operational definition}

Age was the age of the study subjects in the year from birth to the time of study. Length of work was the length of time (in years) from the first time to the cadre to the time the study was conducted. Education was the highest level of formal education achieved by study subjects. Work was an activity that the cadres do to support their life and family life.

Knowledge was everything the cadres know about the main tasks, functions and roles of posyandu cadres. Training was a non-formal education that a cadre learned to improve their skills in carrying out the main tasks and role of posyandu cadres through many types of training.

Posyandu revitalization strategy was an effort to empower the posyandu through the approach of Community Based Health Effort (UKBM). The cadre's activeness was 
a cadre's involvement of in various posyandu activities both inside and outside posyandu.

\section{Data analysis}

Univariate analysis used frequency distribution test and percentage of each variable. Bivariate analysis used Chi Square test. Multivariate analysis used multiple logistic regression test.

\section{RESULTS \\ 1. Bivariate analysis result \\ Bivariate analysis result showed that the work $(\mathrm{OR}=12.63$; 95\% $\mathrm{CI}=3.31$ to 48.18 ; $\mathrm{p}$ $<0.001)$, training $(\mathrm{OR}=9.05 ; 95 \% \mathrm{CI}=3.27$ to 25.01; p <0.001), education $(\mathrm{OR}=1.94$; $95 \%=0.71$ to $5.29, \mathrm{p}=0.290)$ and long time to cadre $(\mathrm{OR}=1.98 ; 95 \% \mathrm{CI}=0.81$ to $4.86 ; \mathrm{p}$ $=0.199$ ) were related to increase cadre activeness.}

Table 1. ANOVA test result of factors related to posyandu cadre activeness

\begin{tabular}{lcccc}
\hline \multirow{2}{*}{ Variable } & \multirow{2}{*}{ OR } & \multicolumn{2}{c}{ 95\% CI } & \multirow{2}{*}{ p } \\
\cline { 3 - 4 } & & Lower limit & Upper limit & \\
\hline Cadre age $\geq 46$ years & 0.18 & 0.01 & 3.66 & 0.262 \\
Cadre duration ( $\geq 1$ 10 years) & 1.53 & 0.42 & 5.61 & 0.524 \\
Education $\geq$ Senior high school & 2.35 & 0.47 & 11.76 & 0.299 \\
Less education & 0.80 & 0.16 & 4.02 & 0.786 \\
House wife & 9.58 & 1.60 & 57.21 & 0.013 \\
Having ever attended training & $4.38 ;$ & 1.21 & 15.77 & 0.024 \\
Good revitalization strategy & 3.71 & 1.03 & 13.36 & 0.045 \\
\hline
\end{tabular}

Age of cadre $\geq 46$ years $(\mathrm{OR}=0.18 ; 95 \% \mathrm{CI}$ $=0.01$ to $3.66 ; \mathrm{p}=0.262)$, less knowledge $(\mathrm{OR}=0.80 ; 95 \% \mathrm{CI}=0.16$ to $4.02 ; \mathrm{p}=$ o.786) was related to the decreased cadre activity.

\section{DISCUSSION}

The study result showed that most (53.8\%) study subjects of activeness of posyandu activity were high and almost half (46.3\%) of study subjects of activity of posyandu activity was low. The cadresactiveness in posyandu is an effort to launch the process that will be given to the community. From thisstudyresult, it can be seen that high
Knowledge $(\mathrm{OR}=0.20 ; 95 \% \mathrm{CI}=$ 0.043 to $0.94 ; \mathrm{p}=0.007)$, age $(\mathrm{OR}=0.17$; 95\% CI $=0.01$ to $2.98 ; \mathrm{p}=0.086)$; and revitalization strategy $(\mathrm{OR}=6.97 ; 95 \% \mathrm{CI}=$ 2.57 to 18.91 ; $p<0.001$ ) affected the liveliness of the cadre.

\section{Multivariate analysis result}

Based on the results of multivariate analysis in Table 1, it was known that the length of the cadre ( $\geq 10$ years) $(\mathrm{OR}=1.53$, $95 \% \mathrm{CI}=0.42$ to $5.61 ; \mathrm{p}=0.524)$, education $\geq$ senior high school $(\mathrm{OR}=2.35$; 95\% CI $=$ 0.47 to $(\mathrm{OR}=9.58 ; 95 \% \mathrm{CI}=1.60$ to 57.21 ; $\mathrm{p}=0.013)$, having attended training (OR = 4.38; $95 \% \mathrm{CI}=1.21$ to $15.77 \mathrm{p}=0.024)$. Good revitalization strategy $(\mathrm{OR}=3.71$, $95 \% \mathrm{CI}=1.03$ to $13.36, \mathrm{p}=0.045)$ were related to increase cadre activeness. activeness samples in posyanduare more than the low activeness cadres. The activeeness of posyandu cadres was influenced by several factors. In thisstudy, the factors studied were cadre characteristics (age, cadre duration, education, occupation, knowledge, training) and revitalization strategy.

\section{Effect of age on cadre activity}

The study results showed that 4 cadres $46-$ 55 years old (adult age) half (50\%) were high and less activeness, while the study subjects 26-45 years (young adults) was mostly (58\%) high activeness, -25 years (teens) mostly (85.7\%) were less activeness. 
Journal of Health Promotion and Behavior (2017), 2(3): 282-290

https://doi.org/10.26911/thejhpb.2017.02.03.08

According to Iqbal (2006), increasingthe age, then the productivity decreases, this is because the physical skills will decrease by age but experience and maturity of the soul will increase.

The bivariate analysis result of age effect on cadre activeness showed no significant effect with $\mathrm{p}=0,086$. Age (2645 years) $(\mathrm{OR}=0.17 ; 95 \% \mathrm{CI}=0.01$ to 2.98). It can be concluded that the age of the cadres was not a risk factor and the statistically age factor did not show a significant relationship with the activeness of posyandu cadres.

This study was in line with Maretha (2010) which states there is no relation between age and cadre response to the community visit at Posyandu, Jatimulya community health center. The role possibility of cadre in posyandu in Jatimulya community health center was not influenced by age, both old and young cadres participated in posyandu activity.

There was no regulation stating the employment limits and one's age could become a cadre, so there were still cadres who were elderly but still became a cadre.

This led to a decrease of a cadre activity as the age of physical skills decreases. While in adolescence (17-25 years) the maturity level in thinking was still less and still busy in taking care of the household, so the activenesswas also low. While at the age of 26-45 years (young adults) the activity was high because their mental and physical maturity was still good so that more active in posyandu activities.

For cadres in charge of monthly recording and reporting of posyandu activities in the age of 46-55 years required regeneration by cadres in the age of 26-45 years and for older cadres might be given other easier tasks based on their physical abilities.

\section{Effect of duration on cadre activity}

The results showed 44 subjects who had long been cadre were most (61.4\%) with high activeness, while 36 new study subjects became cadres mostly (55.6\%) low activeness level. Study subjects which had long become a cadre had high chance of active cadre of 1.98 times compared to new study subjects becoming cadre $(\mathrm{OR}=1.98$; $95 \% \mathrm{CI}=0.81$ to $4.86 ; \mathrm{p}=0.199$ ).

The study results were in line with the study of Rizqa (2011) stated that there was no relationship between long being a posyandu cadre with the behavior of delivering information about balanced nutriation messages. According to Widiastuti (2006) the longer a cadre's work duration is, the more experience he or she has so that it can be used as a basis for action or taking decisions. Instead the new cadres do not have much experience as well as foreign and doubtful. This condition will hamper its participation in an activity.

The activeness of attending posyandu activities can be used as a work parameter, this can be seen from the duration someone works. as well as posyandu cadres, the longer a person becomes a posyandu cadre, the higher the activeness and skills in carrying out the tasks at the time posyandu activities will be so that the participation of cadres in posyandu activities will be better. there is no relationship between the duration of becoming a cadre with the activities of the cadres, it is estimated because the longer being a posyandu cadre, she or he may not necessarily increase his or her actrivity because of the busyness or already saturated and feel that it is the time of others replacing as a cadre.

\section{Effect of education on cadre activity}

The study result showed that the study subjects with higher education were mostly (65.2\%) with high activeness, while the 
subject of study with senior high school was mostly (50.9\%) low activeness level. Study subjects with high education had high possibility of active cadres as many as $\mathbf{1 . 9 4}$ times compared to subjects with secondary education $(\mathrm{OR}=1.94 ; 95 \% \mathrm{CI}=0.71$ to 5.29; $\mathrm{p}=0.290$ ).

This showed that the behavior of study subjects in improving the cadre's activeness in the implementation of posyandu activities was very complex, not soley influenced by the education level of study subjects itself in improving the activeness of cadres in the implementation of posyandu activities. A cadre behaves in a certain way in realizing his activeness, this is because of the support (motive) that moved his heart to do something, each cadre of different motives depending on educational background, experience, and knowledge.

This study was in line with Nilawatistudy (2008) showed that educational variable had no significant effect on cadre activeness. This study did not agree with the statement Notoatmodjo (2010) stated that knowledge and education is very important and domaint for the formation of a person's behavior. However, according to Festinger's study (Robbins, 2003) stated that there might be differences between education and behavior, called as cognitive dissonation.

Based on the above statement can be illustrated that the education of a good study subject was supported by the high formal education level of the cadres, namely more than high school, but related to its activeness in conducting posyandu activities. Many factors and other variables were not observed in this study affecting the activeness level of cadre.

\section{Effect of working status on cadre activity}

The result showed that the study subjects as housewives (unemployment) were as many as $67.8 \%$ active in cadres, while the subject of study working as an entrepreneur as many as $\mathbf{8 5 . 7 \%}$ had the activeness level as a low cadre.

Study subjects unemployed had high chance of activeness cadres as many as 12.31 times compared to the study subjects that worked $(\mathrm{OR}=12.63 ; 95 \% \mathrm{CI}=3.31$ to 48.18; $\mathrm{p}<0.001)$.

The studyresults were in line with Cahyaningrum (2015) stated that there was a relationship between mother's activeness in posyandu activities. Working for posyandu cadres will have an impact on family life and the time for parenting will be reduced, so that the under-five mother who has to work outside her time to participate in a posyandu may be very poor or there is no time at all to participate in the dispensary. While the housewife may have more time to actively participate in posyandu activities.

Based on the studyresult, it was stated that posyandu cadres only work in the house or as entrepreneurs. Employed moms at home still have free time to be a posyandu cadre. But sometimes when mothers have a lot of things to do, mother will reduce their activeness as a cadre. Unlike the housewives who have more free time so they can be active to attend the posyandu activities.

\section{Effet of knowledge on cadre activity}

Study subjects with good knowledge were mostly (65.2\%) with high activeness, while the study subjects withless knowledge were most (73.9\%) low activeness level. There was a correlation between knowledge of active posyandu cadre (OR $=0.19 ; 95 \% \mathrm{CI}$ $=0.06$ to $0.57 ; \mathrm{p}=0.007)$. Study subjects 
Journal of Health Promotion and Behavior (2017), 2(3): 282-290

https://doi.org/10.26911/thejhpb.2017.02.03.08

with sufficient knowledge were high possibility of activeness of cadres as many as 0.19 times compared to study subjects with good knowledge.

In line with study conducted by Nonce et al. (2015), there was a significant relationship between knowledge with the activeness of posyandu cadres. According to Notoatmodjo (2010) that one of the factors affecting the activeness level of cadre is the knowledge level.

Knowledge is a very important domain in shaping one's actions or behavior. Based on experience, it was evident that knowledge-based behaviors would be more lasting than behavior not based on know-ledge. Lack of knowledge on posyandu will have a direct and indirect impact on maternal obedience behavior to take advan-tage of posyandu. Therefore a posyandu cadre must have good knowledge about posyandu in order to motivate himself/ herself to be more actively in every posyandu activity.

The high level of cadre knowledge makes its performance as a good cadre and has an impact on the implementation of posyandu program. The better the knowledge level of a cadre, the better the activeness level in the process of posyandu implementation.

\section{Training effect on cadre activity}

The results showed that subjects having attended the training were mostly (78\%) with high activeness, while the subjects never getting training were mostly (71.8\%) with low activeness level. There was training affected posyandu cadre activity in Jember (OR = 9.05; 95\% CI = 3.27 to 25.01; $\mathrm{p}<$ o.001). Study subjects having ever getting training had the chance of high activeness as many as 9.05 times compared to subjects who never received training.

This was in accordance with study conducted by Rewanti et al., (2012) that the training of cadres had an effect on increasing the activity of posyandu cadres. According to Syafei (2008) training is something continuously done, because one's education is essentially never ending. Training of cadres is one of the efforts in increasing knowledge, skill, and cadre's independence. Usually training of cadres is done by the community health center or local health office.

The training gained by posyandu cadres helped to increase cadre'sactiveness and participation in every Posyandu activity. According to MOHRI (2011) training is an effort activity implemented to improve ability, knowledge, technical skill and cadre's dedication.

According to the study assumption that cadre training is really needed to be implemented and made into a planned and sustainable program because the cadre training will give additional knowledge/ understanding to the posyandu program so that with good knowledge it is expected the cadre motivation and activeness in posyandu activity better.

\section{7. effect of revitalization strategy on cadre activity}

The results showed that most study subjects with good revitalization strategy (72.3\%) tend to be active as cadres. Study subjects with less revitalization strategy (72.7\%) had low activeness level.

Good revitalization strategy was increased posyandu cadre activity in Jember (OR $=6.97 ; 95 \% \mathrm{CI}=2.57$ to 18.91 ; $\mathrm{p}<0.001$ ). Posyandu revitalization program has a purpose to increase function and performance of posyandu, with main activities are; 1) training, to improve cadre ability and quality; 2) services, including five priority programs that are minimal packages targeting children under five and pregnant and breastfeeding women and; 3) community mobilization. The effort has 
been initiated through various activities such as socialization, training and posyan$\mathrm{du}$ revitalization workshops throughout 1999-2000 (Ridwan et al., 2007).

In line with Nilawati (2008) study, the revitalization strategy (stakeholder support) could significantly improve the activeness of cadres in the implementation of posyandu activities in Samadua subdistrict, South Aceh district.

The revitalization strategy in this case was government's support through government's apparatus such as village head, puskesmas institution by means of infrastructure. Village head as a leader in a region has a very big influence on the smoothness of posyandu and the activeness of cadres in the implementation of posyandu activities. Head village participation to invite the commu-nity to come to posyandu can give big contribution for the cadres, the implementation of posyandu is the collective responsibility of all society, government and other related parties. The activeness of all parties is a pillar of success and survival of Posyadu to support revitalization.

The result of multivariate analysis simultaneously found significant value between independent variable (cadre characteristicand revitalization strategy) and dependent variable (cadre activeness) meaning independent variable fulfill the requirement of simultaneous test (model fit).

The Wald test results showed that the work, training, and revitalization strategy had an effect on cadre activity. The dominant factor of cadre activeness in this studywas the employment status (Wald = $6.14 ; \mathrm{p}=0.013)$.

The cadre economy background was still relatively low making cadres prefer to work especially if their job as a busy entrepreneur. But if there was a spare time, cadres start actively again. This was because becoming a posyandu cadre was a social activity. Therefore, there should be attention and appreciation in form of extra money and infrastructure facilities from the local government so that the cadres are more active.

According to Irawati's opinion (2000) in Nilawati (2008), stated that the lack of activeness level of cadre in every posyandu activity was related to the compensation received by the cadre itself, and there was no attention and appreciation from the local government either in the form of material or non reward material, such as cadre uniforms worn at every posyandu activity.

\begin{tabular}{l}
\hline REFERENCE \\
\hline Departemen kesesehatan RI (2011). Pe- \\
doman Umum pengelolaan Posyandu. \\
Jakarta: Departemen Kesehatan RI \\
dan Kelompok Kerja Oprasional \\
(POKJANAL POSYANDU).
\end{tabular}

Fitria (2010). Tanggapan kader terhadap kunjungan masyarakat di posyandu serta faktor-faktor yang berhubungan di Puskesmas Jatimulya Kecamatan Tambun Selatan Kabupaten Bekasi.

Iqbal W (2006). Ilmu KeperawatanKomunitas 2. Jakarta: CV. SagungSeto.

Nilawati (2008). Pengaruh Karakteristik Kader Dan Strategi Revitalisasi Posyandu Terhadap Keaktifan Kader Di Kecamatan Samadua Kabupaten Aceh Selatan.

Nonce L (2015). Faktor Yang Berhubungan Dengan Keaktifan Kader Posyandu Di Wilayah Kerja Puskesmas Ranotana Weru. Jurnal. Gizido, 7(2). Jurusan Gizi Poltekkes Kemenkes Manado.

Rewanti (2012). Faktor-faktor yang berhubungan dengan keaktifan kader posyandu di wilayah kerja puskesmas tareran kabupaten Minahasa. Skripsi. 
Journal of Health Promotion and Behavior (2017), 2(3): 282-290

https://doi.org/10.26911/thejhpb.2017.02.03.08

Universitas Hasanuddin, Ujung Padang.

Ridwan (2007). Revitalisasi Posyandu Pengaruhnya terhadap Kinerja Posyandu di Kabupaten Tenggamus, Magister Kebijakan dan Manajemen Pelayanan Kesehatan (KMPK), Universitas Gadjah Mada, Working Paper Series No.16 Juli 2007.

Salman A (2013). Faktor-Faktor Yang Mempengaruhi Peran Kader Dalam Revitalisasi Posyandu Di Desa Sukamurni Kabupaten Bekasi.

Sriati A, Hernawaty T, Anna A (2014). Pemberdayaan Kader Dan Revitalisasi Posyandu Dalam Meningkatkan Derajat Kesehatan Reproduksi Di Desa Anjun Dan Babakan Sari Kecamatan Plered Kabupaten Purwakarta.
Sriyatty W, Sengkey GD, Kandou JM, Pangemanan (2015). Analisis Kinerja Kader Posyandu di Puskesmas Paniki Kota Manado.

Syafei M (2008). Pemberdayaan Kader dalam Revitalisasi Posyandu di Kabupaten Batang Hari. Working Paper Series No. 14 April 2014.

Widiastuti A (2007). Faktor-faktor yang berhubungan dengan partisipasi kader dalam kegiatan posyandu di Kelurahan Gubug Kecamatan Gubug Kabupaten Grobogan tahun 2006. Dalam Karya Ilmiah Akhir pada Program Strata 1 Universitas Negeri Semarang.

Zakaria A (2013). Evaluasi Pasca Revitalisasi Pelayanan Kesehatan Di Posyandu Kota Surabaya. 